\title{
Laboratory Populations: Is It Representative for Bioassays in Relation to Field Populations of Oriental Fruit Moth?
}

\author{
Rosangela Teixeira ${ }^{1}$, Lino B. Monteiro ${ }^{1}$, Izonete C. Guiloski ${ }^{2}$, Helena C. Silva de Assis ${ }^{2}$ \& Anderson E. Zanatta ${ }^{1}$ \\ ${ }^{1}$ Laboratório de Manejo Integrado de Pragas, LAMIP Universidade Federal do Paraná, Paraná, Brazil \\ ${ }^{2}$ Laboratório de Toxicologia Ambiental, Universidade Federal do Paraná, Paraná, Brazil \\ Correspondence: Lino B. Monteiro, Laboratorio Manejo Integrado de Pragas, Universidade Federal do Paraná, \\ Rua dos Funcionários, 1540, Curitiba, PR 88035050, Paraná, Brazil. Tel: 55-41-3350-5671. E-mail: \\ lbmonteiro@terra.com.br
}

Received: January 29, 2016 Accepted: May 4, 2016 Online Published: June 15, 2016

doi:10.5539/jas.v8n7p61 URL: http://dx.doi.org/10.5539/jas.v8n7p61

\begin{abstract}
The use of laboratory insects for physiological studies, both genetic and toxicological, has become very common, but the continuous strains available in the laboratory for several generations without the insertion of genetic material can change the wild phenotypic and behavioral characteristics of the population compared with the field population. The aim of this research was to evaluate susceptility of field and laboratory Oriental Fruit Moth populations with the insecticide, based in toxicological, biochemical, and physicochemical characteristics. Experiments were conducted with four groups of chemical insecticides serving as chlorpyrifos, carbaryl, deltamethrin, and tebufenozide, with seven concentrations defined after pilot testing. Thereafter, the activity of acetylcholinesterase (AchE), glutathione S-transferase (GST), and Near Infrared Spectroscopy (NIRS) was evaluated. It was possible to detect differences between populations with regard to carbaryl and chlorpyrifos insecticides. The infrared analysis showed that the populations were distinct from each other, and they exhibit high activity of GST and AchE. The populations from both the field and the laboratory are different in their susceptibility to insecticides.
\end{abstract}

Keywords: enzymatic activity, genetic variability, Grapholita molesta, near infrared spectroscopy, toxicology

\section{Introduction}

Grapholita molesta (Busk, 1916) (Lepidoptera: Tortricidae), is a major pest on apple and peach trees. In Brazil, its presence has been recorded on peach trees since 1929 (Gonzales, 1986) and on apple trees since the 1980s (Lorenzato, 1988). The larvae developed earlier in peach plants and the adults migrated to apple cultivars that have late cycle. The larvae damages are similar in both fruit species, such as galleries in branches and fruit (Reis et al., 1998; Natale et al., 2003). The control in the 1980s and 1990s, was with pyrethroids and organophosphates, and in the late 1990s, insecticides growth regulators were registered, among them, belonging to the group diacylhidrazine. Thus, there was an increase in the prevalence of pesticides in the last 10 years, which may be related to the resistance individuals (Kanga et al., 2003; Jones et al., 2010; Siegwart et al., 2011). For study of resistance should multiplicate insects in laboratory. The continued use of arthropods in the laboratory for several generations can modify the phenotypic and behavioral characteristics as compared with the wild population (Leppla et al., 1983).

The bioassays in laboratory are a common practice among researchers. Many of them not specific the number of generations populations tested and which time that this population remained in the laboratory without have been introduced new genetic material. This is often questioned when insects are used to replicate in laboratory studies (Bravo \& Neto, 2004). The laboratory populations cannot express the evolution promoted by modification of environment (Onstad, 2008). Moreover, insects are influenced by the agronomic practices (Ricci et al., 2009) and the dispersion of insects, as occurs between pests of peach and apple (Allen \& Brunson, 1943). The genetic alterations caused by environmental parameters can be assessed by biological and biochemical parameters (Dres \& Malet, 2002; Burd \& Porter, 2006).

The mechanism related to inhibition of the insecticides in tortricidae has been studied in different regions (Kanga, et al., 2003; Reyes \& Sauphanor, 2008). The quantitative methods can be complemented by qualitative as near 
infrared (NIRS) (Teixeira et al., 2015). This may be used to identifications of components quantitative and qualitative, included functional attributes that reflect interactions between insect and environmental factors (Vance et al., 2016).

The objective of this study was to evaluate two populations of Oriental Fruit Moth how much susceptibility comparing replicate laboratory population for three years with the population collected in the same apple orchard, based in toxicological, biochemical and physicochemical characteristics.

\section{Materials and Methods}

\subsection{Insect}

Individual Grapholita molesta specimens were sampled in apple orchards in fruit damage in the Porto Amazonas

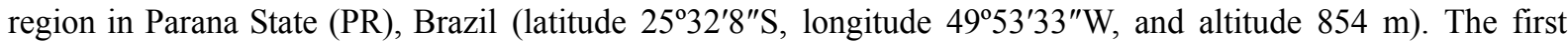
sampling was done in February 2008 and was mantained in the laboratory on an artificial diet (GUENNELON et al. 1981) for 36 generations without the introduction of new genetic material called population 2008 (P2008). The second sample was done in February 2011 in the same portion of the orchard and was maintained under the same conditions of diet for three generations, called population 2011 (P2011).

\subsection{Area Studied}

The orchard of study is constituted of peach, prune and apple plants. The pesticides applied for G. molesta and Anastrepha fraterculus (Diptera: Tephritidae) were on average 6.0 spraying with organophosphate insecticides (chlorpyrifos, fenitrothion, and malathion); 0.5 spraying with diacylhydrazine (tebufenozide); and 1,0 with carbamate (carbaryl) per production cycle on last five years.

\subsection{Bioassays}

Bioassays that assess the toxicity of insecticides were performed in ELISA microplate ( 96 wells) wells filled with $150 \mu 1$ of an artificial diet (Soybean-Wheat Germ Insect Diet, Stonefly Industries, TX, EUA). A volume of $6 \mu \mathrm{L}$ of each concentration of insecticide solution was applied to the diet's surface according to Reyes and Sauphanor (2008). The insecticides tested were chlorpyrifos (Lorsban ${ }^{\circledR} 480$ BR, Dow AgroSciences), deltamethrin (Decis ${ }^{\circledR}$, Bayer CropScience), carbaryl (Sevin ${ }^{\circledR}$ SL, Bayer CropScience), and tebufenozide (Mimic ${ }^{\circledR} 240$ SC, Dow AgroSciences), in seven concentrations giving between zero and $100 \%$ mortality were used, defined from the pilot tests. Three replicates were performed. After drying for $20^{\prime}$ at $22 \pm 2{ }^{\circ} \mathrm{C}$, a larvae was placed in each well, with a total of 24 individuals per concentration. Neonate with three hours of live was handled with a fine-tip brush. The microplate wells were sealed with parafilm to prevent leakage of the caterpillar and dehydration of the diet. The mortality was observed after seven days, and the dead ones were those who did not respond to the touch of the brush. A probit analysis on corrected mortalities (Abbott, 1925) was done to determine the $\mathrm{LC}_{50}$ values (Raymond, 1985).

\subsection{Enzymatic Activities}

The acetylcholinesterase (AChE) and glutathione S-transferase (GST) analyses were carred out with pools $(\mathrm{n}=$ $10)$, with five larvae, from the $3^{\circ}$ to $5^{\circ}$ instar $(n=50)$. The pools were homogenized in the ratio of $1: 10$ (weight:volume) in potassium phosphate buffer $0,1 \mathrm{M}(\mathrm{pH} 7,0)$ with a microhomogenizer and centrifuged $\left(10.000 \times \mathrm{g}\right.$ for $20 \mathrm{~min}$ at $\left.4{ }^{\circ} \mathrm{C}\right)$. The supernatant was used for the determination of enzymatic activities (Bouvier et al., 2002).

The activities of glutathione S-transferase were measured based on the KEEN et al. (1976) method at $340 \mathrm{~nm}$. Overall, $20 \mu \mathrm{L}$ of the extract in the microplate and $180 \mu \mathrm{L}$ of a solution containing $(0.6 \mathrm{mM} \mathrm{GSH} \mathrm{a}, 0.5 \mathrm{mM}$ CDNB a) were added.

The activities of acetylcholinesterase were measured at $405 \mathrm{~nm}$ by the ELLMAN et al. (1965) method that was modified to the microplate by Silva de Assis (1998). In the microplate, $50 \mu \mathrm{L}$ of the extract and $200 \mu \mathrm{L}$ of DTNB were added (5,5-ditio-bis-2-nitrobenzoate $0.75 \mathrm{mM})$ and $50 \mu \mathrm{L}$ substrate acetiltiocoline $10 \mathrm{mM}$.

The protein concentration was determined by the Bradford method (1976) by using bovine serum albumin as a standard. A microplate spectrophotometer TECAN A 5082 was used for measurements, and the results of the enzymatic activities were expressed in $\mathrm{nmol} \mathrm{min}^{-1} \mathrm{mg}$ protein ${ }^{-1}$.

\subsection{Infrared}

The spectra were obtained using a Bio-Rad Excalibur FTS 3500 GX spectrophotometer (Bio-Rad Laboratories, Cambridge, MA, USA) operated in the 800 to $2500 \mathrm{~nm}$ region. The spectral range was 7500 to $4000 \mathrm{~cm}^{-1}(1428$ to $2500 \mathrm{~nm}$ ), with a resolution of $1 \mathrm{~cm}^{-1}$. Overall, 32 scans were performed for each individual insect. In each 
population, 50 pupae were analyzed and performed with a white mirror unit to be used as reference samples. The spectrum were transformed using the first derivative of Savitzky-Golay (21-point window and second-order polynomial). The ability to differentiate between the two populations at each stage was evaluated using discriminant analysis with least partial squares (PLS-DA). Each specimen from each population was coded as 0 or 1, for P20011 or P2008, respectively.

The Savistky-Golay model obtained for two separate populations was validated externally by means of external samples, and the reference values were 0 (P2008) and 1.0 (P2011). The values not exceeding 0.5 of the deviation from the reference set were considered appropriate. The multivariate calibration models were developed using the Unscrambler ${ }^{\mathrm{TM}}$ program, Version 9.7 (Camo Software AS, Oslo, Norway).

\subsection{Statistical Analysis}

The concentration-mortality data were subjected to probit analysis. Mortalities to the diagnostic concentration in the field population were compared to that laboratory using a $\chi^{2}$ test after Abbott's correction. Data activity enzymes were calculated as the quotient between the mean activity in field populations and the mean activity laboratory population, expressed as mean \pm standard error of the mean. Analysis of variance (ANOVA) was utilized by determining the differences of the results in the groups. Values of $P<0.05$ were considered significant by the Tukey test.

\section{Results}

\subsection{Bioassays}

The results showed the probit model adjusted to the concentration response data for all bioassays. The response to $\mathrm{CL}_{50}$ larvae originated from relatives of the population collected in 2011 (P2011) and was significantly different in relation to P2008 for the insecticides chlorpyrifos and carbaryl (Table 1). Analyzing the $\chi^{2}$, the hypothesis of equality between populations in relation to the effects of insecticides was rejected, showing that the P2008 was more susceptible than in P2011.

Table 1. Evaluation of $\mathrm{CL}_{50}$ of four chemical insecticides for populations multiplied in the laboratory (P2008) and the field population (P2011) Grapholita molesta sampled in apple orchards in the same location

\begin{tabular}{lcccccc}
\hline Population & $\mathrm{N}$ & ${ }^{\mathrm{III}}$ Corrected mortality $\%$ & ${ }^{\mathrm{I}} \chi^{2} / \mathrm{GL}$ & $\mathrm{CL}_{50} \mu \mathrm{g} / \mathrm{g}(95 \%)$ & ${ }^{\mathrm{II}} \mathrm{RLC}_{50}$ & Slope $\pm \mathrm{SE}$ \\
\hline $\begin{array}{l}\text { Chlorpyrifos } \\
\text { P2011 }\end{array}$ & 504 & 87.00 & $0.18^{*}$ & $6.84(5.89-7.83)$ & 8.10 & $2.17 \pm 0.21$ \\
P2008 & 504 & 83.33 & $4.60^{*}$ & $0.84(0.12-5.14)$ & & $0.51 \pm 0.05$ \\
\hline Tebufenozide & & & & & \\
P2011 & 504 & 75.50 & 0.10 & $8.27(6.66-10.05)$ & 0.65 & $1.45 \pm 0.02$ \\
P2008 & 504 & 62.50 & 0.07 & $12.66(9.95-17.41)$ & & $1.15 \pm 0.20$ \\
\hline Carbaryl & 504 & 83.33 & & & & \\
P2011 & 504 & 59.00 & $0.23^{*}$ & $10.91(8.40-14.23)$ & 11.28 & $1.23 \pm 0.01$ \\
P2008 & & $4.74^{*}$ & $0.96(0.12-6.49)$ & & $0.04 \pm 0.05$ \\
\hline Deltrametrin & 504 & 93.50 & & & & \\
P2011 & 504 & 88.50 & 1.32 & $5.12(3.09-8.33)$ & 0.74 & $1.06 \pm 0.009$ \\
P2008 & 1.65 & $6.87(3.16-15.45)$ & & $0.72 \pm 0.084$ \\
\hline
\end{tabular}

Note. *: Indicated significant lack of fit at $\mathrm{p}=0.05$. Polo plus, uses the factor of heterogeneity factor to calculate of estimate of slope $\mathrm{CL}_{50}$ and $\mathrm{CL}_{95}$; **: Rate of lethal concentration $\mathrm{CL}_{50}$ and $\mathrm{CL}_{95}$ between P2008 and P2011; ***: Insecticide concentration in ppm in diet based in higher dosage.

The rate of lethal concentration (RLC) for P2011 was around 8-11 times higher, respectively, for chlorpyrifos and carbaryl. The responses of the larvae of P2011 for the concentrations of deltamethrin and tebufenozide were similar among the populations. The response of the larvae in $\mathrm{CL}_{95}$ was not different between P2011 and P2008 for all treatments (data not reported). The corrected mortality of the larvae of P2011 was greater than that found in P2008 for chlorpyrifos and carbaryl. There was a positive correlation $(r=0.99)$ between corrected mortality 
and $\mathrm{LC}_{50}$ for chlorpyrifos and carbaryl, showing a variation for these products that was directly proportional and inverse to the other insecticides $(\mathrm{r}=-0.99)$. Despite the significance of the $\mathrm{LC}_{50}$ values for chlorpyrifos, the corrected mortality of larvae between the two populations was small, which was around 3.5\%. The same did not occur with carbaryl, which was plus high, around $24 \%$, between populations.

\subsection{Biochemistry}

The enzymatic activity of acetylcholinesterase larvae multiplied in the laboratory for 36 generations (P2008) was lower than the larvae of $\mathrm{P} 2011(\mathrm{~F}=2.73, \mathrm{df}=1$, and $\mathrm{P}=0.014)$, which was around 47.5\% (Figure 1). The GST activity was significantly high for larvae of $\mathrm{P} 2011(\mathrm{~F}=11.45, \mathrm{df}=1$, and $\mathrm{P}=0.0147)$.

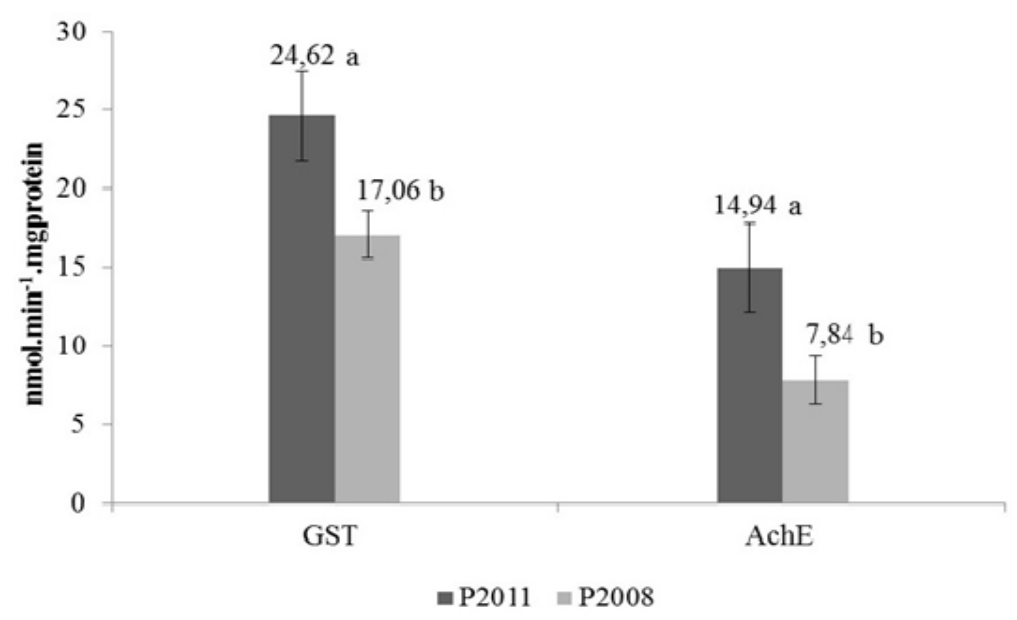

Figure 1. Enzymatic activities of Glutathione S-Transferase and Acetylcholinesterase of two populations of Grapholita molesta, submitted to a laboratory condition and a wild population

\subsection{Near Infrared}

The technique of NIRS was able to distinguish between the laboratory and wild populations. The performance of PLS calibration models were evaluated by $\mathrm{R}^{2}$, RMSEC, RMSEV and $\mathrm{R}^{2} \mathrm{~V}$, correlation was good, with values for R2, respectively, 0.98 and 0.94, considering the two populations and lower values of RMSEV and RMSEC with values for RMSEC 0.0006 and 0.02 and RMSEV 0.05 and 0.01 respectively the P2008 and P2011. External validation is essential to confirm the quality of the model. Prediction correctly classified $100 \%$ of the external sample set with an RMSEP of 0.15 and 1.04 for P2008 and P2011 respectively. Thus confirming a robust model. 

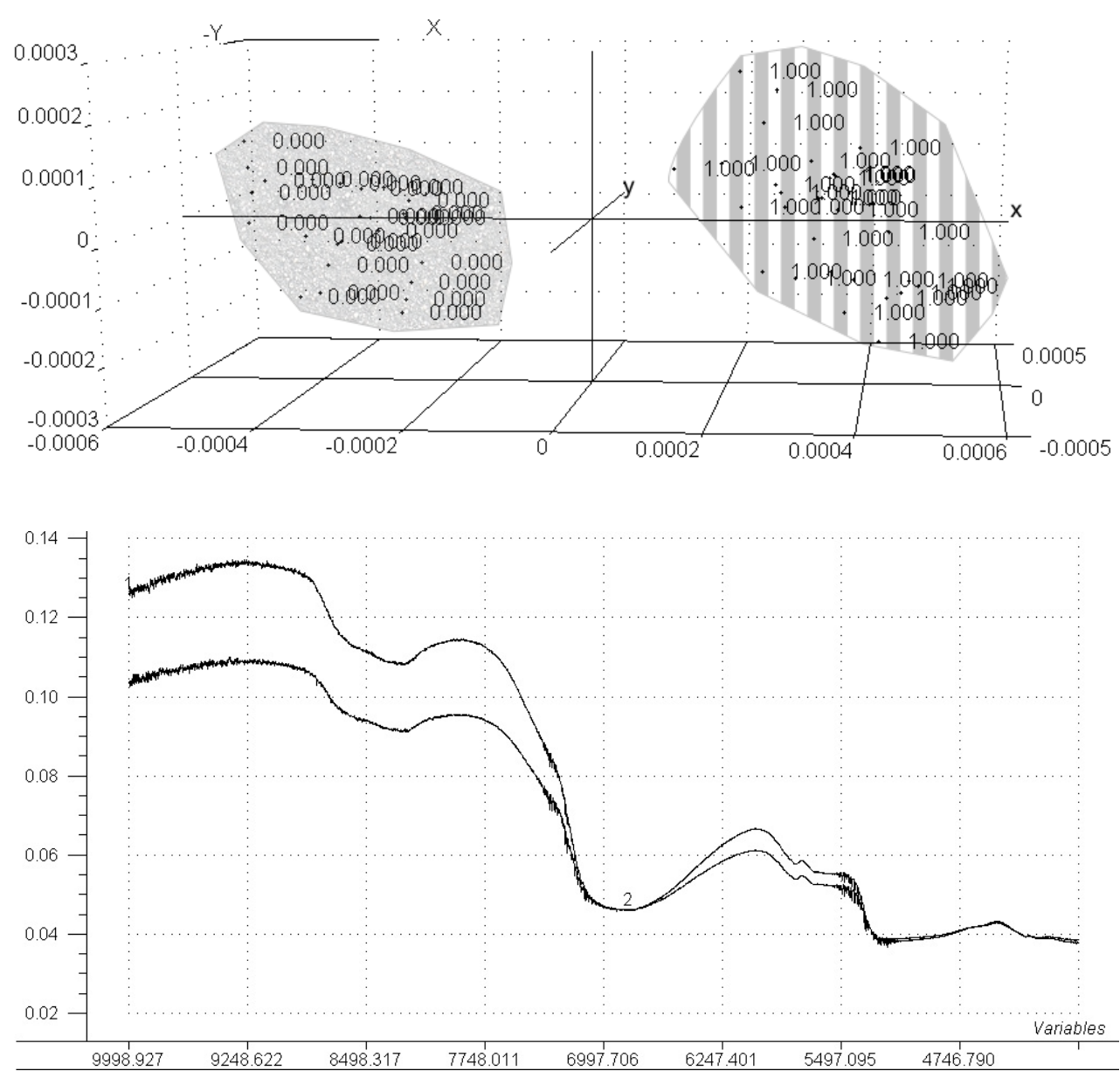

Figure 2. (A) Evaluation of differentiation between two populations of Grapholita molesta collected in the same environment, but on different dates. $=0$ field population and laboratory population $=1.0$. The axis values of the picture displayed for two main components ( $y=90$ and $7 \%, x=17$ and $4 \%, z=0 \%$ ). (B) Raw spectra, without the application of mathematic model of G. molesta populations: 1 = field, 2 = laboratory

The results of NIRS showed that P2008 and P2011 are different (Figure 2A).The beams spectrais in the larvae of G. molesta focus on separate quadrants on the y-axis whose response explained $90 \%$. The y-axis was responsible for the separation of the populations related to the $\mathrm{x}$ and $\mathrm{z}$ axis. Analyzing the raw spectra before applying the statistical model, the two populations meet at a certain point $(6997.706 \mathrm{~nm})$, while differentiating at the beginning of the spectrum (Figure 2B).

\section{Discussion}

The study showed that population G. molesta strains in the laboratory (P2008) presented biochemical and toxicological characteristics which suggest that they are more likely similar to those that suffered phytosanitary pressure in the field (P2011). Although, P2008, which was used in this study, was the same as that used in studies of resistance conducted in 2008 (Siegwart et al., 2011), manifested resistance to chlorpyrifos in relation to a reference population (multiplied in the laboratory for more than 10 years), and showed a higher activity of AchE and GST. When the P2008 was mantained in the laboratory for 36 generations, under the influence of the artificial medium, many physiological and behavioral characteristics were affected, similar to those occurring in Ceratitis capitata (Diptera: Tephritidae) (Bravo \& Neto, 2004) and Grapholita molesta (Jones et al., 2011). The P2011 suffered delection pressure by organophosphates insecticides, due to the increase of pesticide applications in relation to the period before their collected The toxicological analyses showed that the larvae responded to the concentrations of the insecticides chlorpyrifos and carbaryl, but they were more tolerant than the larvae grown in an artificial diet. The process of selection in P2011 was not interrupted, different of P2008 who stopped 
receiving chemical methods. Deltamethrin and tebufenozide are not used often in the orchards, and had no influence on the susceptibility of the population.

Biochemical bioassays showed that P2008 was more susceptible to carbamates and organophosphates relative to P2011. The inhibition of the enzyme is related to the find mechanism of resistance of both chemical groups, as lepidopteros (Yu et al., 2003; Kanga et al., 2003). GST plays a role in different routes of metabolism, protecting cells against chemical toxicity and stress (Chelvanayagam et al., 2001). The presence of this enzyme is often related to resistance to the insecticide Tortricidae (Reyes \& Sauphanor, 2008). The high number of applications of organophosphate insecticides in the Brazilian orchards (Siegwart et al., 2011) exerts selection pressure and may feature a contrived example of natural selection (Ffrench-Constant et al., 2004).

In the absence of selection pressure by insecticides is an instability of resistance alleles in the population (Kanga et al., 2003), and over time, they become susceptible (Orr, 1998). Populations are maintained in the laboratory under pressure of selection of individuals by other factors; in this case, the selection is based on the adaptation of the colony to artificial diets, oviposition, the high density of moths, and multiple mating, in addition to abiotic factors that are always constant in laboratories (Franck et al., 2011).

Qualitative differences between P2008 and P2011 were found with the technique of near infrared spectroscopy (NIRS). This distinction is found to be related to the structural composition of individuals of each population, such as a chemical signature within each species. In this regard, the infrared analysis allows preliminary diagnosis of populations; more complex analysis before identifying these populations not used as reference laboratory toxicological and biochemical tests in the case of representation of a field population. In other studies, using NIRS tool showeds promising results, such as the analysis of the composition of cuticular hydrocarbons ants (Antoniall et al., 2008), of Zootermopsis species (Aldrich et al., 2007) Eucalyptus species and insect-resistant species (Floyd \& Foley, 2001). Thus, the NIRS probably considered the influence of the environments in which they are multiplied.

\section{Conclusion}

An integrated pest management program (IPM) helps to avoid the process of natural selection by using new pesticides with different modes of action. The populations of G. molesta collected in the apple orchard were less susceptible to insecticides that three years laboratory populations when subjected to toxicological and biochemical analysis as well as being different when analyzed by infrared.

\section{References}

Abbott, W. S. (1925). A method of computing the effectiveness of insecticides. Journal Economic Entomology, 18, 265-267. http://dx.doi.org/10.1093/jee/18.2.265a

Aldrich, B. T., Maghirang, E. B., Dowell, F. E., \& Kambhampati, S. (2007). Identification of termite species and subspecies of the genus Zootermopsis using near-infrared reflectance spectroscopy. Journal of Insect Science, 7, 1-7. http://dx.doi.org/10.1673/031.007.1801

Allen, H., \& Brunson, M. (1943). The effect of proximity to apple on the extent of Oriental fruit moth injury in peach orchards. Journal of Economic Entomology, 36, 879-882. http://dx.doi.org/10.1093/jee/36.6.879

Antonialli Junior, W. F., Súarez, Y. R., Izida, T., Andrade, L. H. C., \& Lima, S. M. (2008). Intra- and interspecific variation of cuticular hydrocarbon composition in two Ectatomma species (Hymenoptera: Formicidae) based on Fourier transform infrared photoacoustic spectroscopy. Genetic and Molecular Research, 7, 559-566. http://dx.doi.org/10.4238/vol7-2gmr454

Bouvier, J. C., Boivin, T., Beslay, D., \& Sauphanor, B. (2002). Age-dependent response to insecticides and enzymatic variation in susceptible and resistant codling moth larvae. Arch. Insect Biochemical Physiology, 51, 55-66. http://dx.doi.org/10.1002/arch. 10052

Bradford, M. (1976). A rapid and sensitive method for the quantification of microgram quantities of protein utilizing the principle of protein-dye binding. Analitycal Biochemical, 72, 248-254. http://dx.doi.org/10.1016/0003-2697(76)90527-3

Bravo, J. S. I., \& Neto, S. M. A. (2004). Aceitação e preferência de frutos para oviposição em duas populações de Ceratitis capitata (Diptera: Tephritidae). Iheringia, 94, 171-176. http://dx.doi.org/10.1590/S0073-47212004000200009

Burd, D. J., \& Porter, R. D. (2006). Biotypic Diversity in Greenbug (Hemiptera: Aphididae): Characterizing New Virulence and Host Associations. Journal of Economic Entomology, 99, 959-965. http://dx.doi.org/10.1093/jee/99.3.959 
Ceruti, C. F., \& LazzarI, M. N. S. (2003). Utilização de bioensaios e marcadores moleculares para detecção da resistência de coleópteros de produtos armazenados a inseticidas. Revista Brasileira de entomologia, 47, 447-453. http://dx.doi.org/10.1590/S0085-56262003000300015

Chelvanayagam, G., Parker, M. W., \& Board, P. G. (2001). Fly fishing for GSTs: A unified nomenclature for mammalian and insect glutathione transferases. Chemico Biological Interations, 133, 256-260.

Dres, M., \& Mallet. J. (2002). Host races in plant-feeding insects and their importance in sympatric speciation. Philos. Trans. Proceedings, 357, 471-492. http://dx.doi.org/10.1098/rstb.2002.1059

Ellman, G. L., Coutney, K. O., Andres, V., \& Featherstone, R. M. (1965). A new and rapid colorimetric determination of acetylcholinesterase activity. Biochemical Pharmacology, 7, 88-95. http://dx.doi.org/10.1016/0006-2952(61)90145-9

French-Constant, H. R., Daborn, J. P., \& Goff, L. G. (2004). The genetic and genomics of insecticide resistance. Trends Genetics, 20, 163-170. http://dx.doi.org/10.1016/j.tig.2004.01.003

Floyd, B. R., \& Foley, J. W. (2001). Identifying Pest Resistant Eucalypts using near-infrared spectroscopy. Rural Industries (p. 112). Rural Industries Research and Development Corporation.

Franck, P., Ricci, B., Klein, E. K., Olivares, J., Simon, S., Cornuet, J. M., \& Lavigne, C. (2011). Genetic inferences about the population dynamics of codling moth females at a local scale. Genetica, 139, 949-960. http://dx.doi.org/10.1007/s10709-011-9598-5

González, R. H. (1986). Phenology of the oriental peach moth. Aconex, 12, 5-12.

Guennelon, G. H., Audemard. J., Fremond, C., \& El Idrissi Ammari, M. A. (1981). Progress achieved in permanent rearing of the codling moth (Laspeyresia pomonella L.) on an artificial medium. Agronomy, 1, 59-64. http://dx.doi.org/10.1051/agro:19810108

Jones, M. M., Robertson, J. L., \& Weinzierl, R. A. (2011). Susceptibility of Oriental Fruit Moth (Lepidoptera: Tortricidae) to Two Pyrethroids and a Proposed Diagnostic Dose of Esfenvalerate for Field Detection of Resistance. Journal of Economic Entomology, 104, 1031-1037. http://dx.doi.org/10.1603/EC10399

Kanga, L. H. B., Pree, D. J., Van Lier, J. L., \& Walker, G. M. (2003). Management of insecticide resistance in oriental fruit moth (Grapholita molesta; Lepidoptera: Tortricidae) populations from Ontario. Pest Management Science, 59, 921-927. http://dx.doi.org/10.1002/ps.702

Keen, J. H. (1976). Mechanism for several activities of the glutathione S-transferase. Journal Biologycal Chemistry, 251, 6183-6188.

Leppla, N. C., Huettel, M. D., Chambers, .D. L., Ashley, T. R., Miyashita, D. H., Wong, T. T. Y., \& Harry, E. J. (1983). Strategies for colonization and maintenance of the Mediterranean fruit fly. Entomologia Experimentalis et Applicata, 33, 89-96. http://dx.doi.org/10.1111/j.1570-7458.1983.tb03238.x

Lorenzato, D. (1988). Lepidópteros nocivos em fruteiras rosáceas no Sul do Brasil. Ipagro, 31(7).

Natale, D., Mattiacci, L., Hern, A., Pasqualini, E., \& Dorn, S. (2003). Response of female Cydia molesta (Lepidoptera: Tortricidae) to plant derived volatiles. Bulletin Entomologycal Research, 93, 335-342. http://dx.doi.org/10.1079/ber2003250

Nava, E. D., \& Parra, P. R. J. (2005). Biologia de Stenoma catenifer Walsingham (Lepidoptera: Elachistidae) em Dieta Natural e Artificial e Estabelecimento de um Sistema de Criação. Neotropical Entomology, 34, 751-759. http://dx.doi.org/10.1590/S1519-566X2005000500006

Onstad, D. W. (2008). The role of environment in insect resistance management. In D. W. Onstad (Ed.), Insect Resistance Management: Biology, Economics and Predictions (pp. 209-260). Academic Press, London, UK. http://dx.doi.org/10.1016/B978-012373858-5.50012-5

Orr, H. A. (1998). The population genetics of adaptation: The distribution of factors fixed during adaptive evolution. Evolution, 52, 935-949. http://dx.doi.org/10.2307/2411226

Parra, J. R. P. (2000). O controle biológico e o manejo de pragas: passado, presente e future. In J. V. C. Guedes, I. D. Costa, \& E. Castiglioni (Eds.), Bases e técnicas do manejo de insetos (pp. 59-69). Santa Maria: UFSM/ CCR/DFS.

Raymond, M. (1985). Présentation d'un programme Basic d'analyse log-probit pour microordinateur. Entomol. Med. Parasitol., 23, 117-121. 
Reis, F. W., Nora, I., \& Melzer, R. (1988). Population dynamics of Grapholita molesta (Busck, 1916) and its adaptation on apple in south Brazil. Acta Horticultural, 232, 204-208. http://dx.doi.org/10.17660/ActaHortic.1988.232.27

Reyes, M., \& Sauphanor, B. (2008). Resistance monitoring in codling moth: A need for standardization. Pest Managament Science, 64, 945-953. http://dx.doi.org/10.1002/ps.1588

Ricci, B. Franck, P., Toubon, J. F., Bouvier, J. C., Sauphanour, B., \& Lavigne, C. (2009). The influence of landscape on insect pest dynamics: a case study in southeastern France. Landscape Ecology, 24, 337-349. http://dx.doi.org/10.1007/s10980-008-9308-6

Shearer, W. P., \& Usmani, A. K. (2001). Sex-related response to organophosphorus and carbamate insecticides in adult Oriental fruit moth Grapholita molesta. Pest Managament Science, 57, 822-827. http://dx.doi.org/10.1002/ps.367

Siegwart, M., Monteiro, L. B., Maugin, S., Olivares, J., Carvalho, S. M., \& Sauphanor, B. (2011). Tools for resistance monitoring in Oriental fruit moth (Lepidoptera: Tortricidae) and first assessment in brazilian populations. Journal of Economic Entomology, 104, 636-645. http://dx.doi.org/10.1603/EC10302

Silva de Assis, H. C. (1998). Der Einsatz von Biomarkern zur summarischen Erfassung von Gewässerverschmutzungen ( $\mathrm{PhD}$ thesis, Technical University of Berlin, Germany).

Souza, N. R. (2011). Processos genético-evolutivos e os Recursos fitogenético. Retrieved February 12, 2011, from http://www.inpa.gov.br/cpca/charles/pdf/NSousa_Cap1.pdf

Teixeira, R., Fernandéz, J., Pereira, J., \& Monteiro, L. (2015). Identification of Grapholita molesta (Busk) (Lepidoptera: Tortricidae) biotypes using infrared spectroscopy. Neotropical Entomology, 44, 129. http://dx.doi.org/10.1007/s13744-015-0272-y

Vance, K. C., Tolleson, R. D., Kinoshita, K., Rodriguez, J., \& Foley, J. W. (2016). Near infrared spectroscopy in wildlife and biodiversity. Journal of Nears Infrared Spectroscopy, 24, 01-25. http://dx.doi.org/10.1255/jnirs.1199

Yu, J. S., Guyen, S. N., \& Abo- Elghar, N. (2003). Biochemical characteristics of insecticide resistance in the fall armyworm, Spodoptera frugiperda (J. E. Smith). Pesticide Biochemistry Physiology, 77, 1-11. http://dx.doi.org/10.1016/S0048-3575(03)00079-8

\section{Copyrights}

Copyright for this article is retained by the author(s), with first publication rights granted to the journal.

This is an open-access article distributed under the terms and conditions of the Creative Commons Attribution license (http://creativecommons.org/licenses/by/3.0/). 